\title{
Enhancing the thermotolerance of tomato seedlings by heat shock treatment
}

\author{
Z.Q. YANG ${ }^{* * *}$, C. XU ${ }^{*,+}$, M.T. WANG ${ }^{* * *, \#,+, ~ H . L . ~ Z H A O *, ~ Y . J . ~ Z H E N G ~}{ }^{*}$, H.J. HUANG ${ }^{*}$, F. VUGUZIGA*, \\ and M.A. UMUTONI*
}

Collaborative Innovation Center on Forecast and Evaluation of Meteorological Disasters, Nanjing University of Information Science and Technology, Nanjing, Jiangsu Province, China*

Binjiang College, Nanjing University of Information Science and Technology, Nanjing, Jiangsu Province, China** Sichuan Meteorological Observatory, Chengdu, Sichuan Province, China ${ }^{* * *}$

Water-Saving Agriculture in Southern Hill Area Key Laboratory of Sichuan Province, Chengdu, Sichuan Province, China $^{\#}$

\begin{abstract}
The heat tolerance of tomato seedlings was significantly enhanced after heat shock treatment at $40^{\circ} \mathrm{C}$ for $4 \mathrm{~h}$. Compared with the control, the heat-shocked tomato seedlings, on one hand, had a higher net photosynthetic rate $\left(P_{\mathrm{N}}\right)$, stomatal conductance, intercellular $\mathrm{CO}_{2}$ concentration, water-use efficiency, maximal quantum yield of PSII photochemistry $\left(\mathrm{F}_{\mathrm{v}} / \mathrm{F}_{\mathrm{m}}\right)$, electron transport rate, actual photochemical efficiency of PSII, and activity of antioxidant enzymes, on the other hand, had lower nonphotochemical quenching, relative conductivity, malondialdehyde content (MDA), and accumulation of reactive oxygen species (ROS). In addition, heat shock induced production of heat shock proteins (HSPs) in tomato seedling leaves. HSP70 was significantly negatively correlated with $P_{\mathrm{N}}, \mathrm{F}_{\mathrm{v}} / \mathrm{F}_{\mathrm{m}}$, catalase, superoxide dismutase, and peroxidase and was significantly positively correlated with MDA and ROS. Overall, short-term heat shock treatments, inducing the production of HSPs, helped improve the thermal tolerance of tomato seedlings.
\end{abstract}

Additional key words: chlorophyll fluorescence; high temperature stress; lipid peroxidation; Lycopersicon esculentum; photoinhibition.

\section{Introduction}

Tomato (Lycopersicon esculentum Mill.) is one of the most important horticultural crops and food preference in China, with the cultivation area reaching about a third of the total area of protected crop cultivation (He et al. 2016). It has been reported that tomato plants are sensitive to temperature, especially at vegetative stages, and its optimum growth temperature is between 15 and $32^{\circ} \mathrm{C}$ (Hatfield and Prueger 2015). The term 'heat stress' is generally used for temperatures above the optimum, which produce irreversible injury to plant growth and development (Hütsch et al. 2019). During the summer horticultural cultivation, temperatures tend to reach above $35^{\circ} \mathrm{C}$ or even above $40^{\circ} \mathrm{C}$ in a greenhouse. Therefore, high temperature is considered as the major abiotic stress that limits growth and yield of tomato production in the greenhouse cultivation (Kissoudis et al. 2015).

$\mathrm{Xu}$ et al. (2016) showed that tomato plants exposed to temperatures above their normal growth temperature typically synthesize a group of proteins known as 'heat shock proteins' (HSPs). The synthesis of HSPs has been associated with the development of heat tolerance in a wide variety of organisms (Li et al. 2011). Keeler et al. (2000) found that the expression level of chloroplast HSPs cloned from lima bean (Phaseolus lunatus Linn.) is related to the heat tolerance of plants. Many other studies showed that the rate of thermotolerance development is similar to the rate of HSPs accumulation (Lindquist and Craig 1988, Mahat et al. 2016). In addition, when the plants return to normal temperatures, the decline in heat resistance is synchronized with the degradation of HSPs (Tedeschi et al.

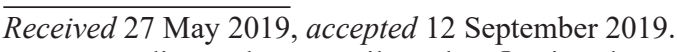

+Corresponding author; e-mail: xuchao@nuist.edu.cn, wangmt0514@163.com

Abbreviations: CAT - catalase; $C_{\mathrm{i}}-$ intercellular $\mathrm{CO}_{2}$ concentration; $E$ - transpiration rate; ETR - electron transport rate; $\mathrm{F}_{0}-$ minimal fluorescence yield of the dark-adapted state; $\mathrm{F}_{0}{ }^{\prime}$ - minimal fluorescence yield of the light-adapted state; FM - fresh mass; $F_{m}-$ maximal fluorescence yield of the dark-adapted state; $\mathrm{F}_{\mathrm{m}}{ }^{\prime}$ - maximal fluorescence yield of the light-adapted state; $\mathrm{F}_{\mathrm{s}}$ - steady-state fluorescence yield; $\mathrm{F}_{\mathrm{v}} / \mathrm{F}_{\mathrm{m}}-$ maximal quantum yield of PSII photochemistry; $g_{\mathrm{s}}-$ stomatal conductance; HSPs - heat shock proteins; $\mathrm{L}_{\mathrm{s}}-$ stomatal limitation; MDA - malondialdehyde content; NPQ - nonphotochemical quenching; $P_{\mathrm{N}}$ - net photosynthetic rate; POD - peroxidase; ROS - reactive oxygen species; SOD - superoxide dismutase; WUE - water-use efficiency; $\Phi_{\mathrm{PSII}}$ - actual photochemical efficiency of PSII.

Acknowledgements: This work was supported by the National Natural Science Foundation of China (41975142, 41775104), the Foundation of Scientific and Technological Development of Meteorological Administration/Heavy Rain and Drought-Flood Disasters in Plateau, and Basin Key Laboratory of Sichuan Province (Key Laboratory of Sichuan Province-2018-Key-05), and the postgraduate Research \& Practice Innovation Program of Jiangsu Province (SJKY19_0965).
} 
2016). HSP70, HSP90, and HSP110, the major heat shock proteins, which are highly conserved among plant species, are correlated to the extent of heat stress, and also play an important role in the response to heat tolerance (Usman et al. 2014). Lurie and Klein (1991) found out that synthesis of HSPs confers heat tolerance in the tissue in which they were formed, so that subsequent exposure to a higher temperature does not cause damage. However, there are few reports on the synthesis of these HSPs that could increase the heat tolerance of tomato seedlings.

Photosynthesis plays an essential role in plant survival, growth, and production (Liang et al. 2018). Key components of the photosynthetic apparatus such as PSII are generally considered to be the most unstable and easily damaged photosynthetic component during a high temperature stress (Camejo et al. 2006). Chlorophyll (Chl) fluorescence is an effective probe for photosynthesis and fluorescence parameters, such as maximum quantum yield efficiency of PSII $\left(\mathrm{F}_{\mathrm{v}} / \mathrm{F}_{\mathrm{m}}\right)$, effective quantum yield of PSII photochemistry $\left(\Phi_{\text {PSII }}\right)$, electron transport rate (ETR), and nonphotochemical quenching (NPQ). Chl fluorescence measurement can be used to assess changes of PSII photochemistry, linear electron flux, and $\mathrm{CO}_{2}$ assimilation in vivo (Maxwell and Johnson 2000, Baker 2008). Lu et al. (2017) demonstrated that the photosynthetic capacity of tomato plants declines gradually and then sharply with leaf senescence under heat stress. During this process, the cell structure, metabolism, and gene expression of leaf cells undergo reversible or irreversible changes. At the same time, the content of reactive oxygen species (ROS) and lipid peroxidation in leaves increases, which in turn causes photoinhibition (Takahashi and Murata 2008). However, in biological systems, antioxidant enzymes, such as catalase (CAT), peroxidase (POD), and superoxide dismutase (SOD), produced in different organelles, play an important role in the fight against oxidative stress and help maintain normal cellular components and metabolic functioning (Begara-Morales et al. 2016). Therefore, measuring the above indicators can effectively clarify whether the plant's growth physiological activities are affected by high temperature stress.

Until now, the photosystem activity and antioxidant response of tomato plants have been studied in response to high temperature stress (Camejo et al. 2005), but studies on enhancement of the thermotolerance of tomato seedlings using heat shock treatment are still rare. Therefore, it was of our interest to see if tomato seedlings exposed to heat shock could protect themselves from high temperature injury. In this paper, the relative expression levels of HSPs in tomato seedlings, induced by heat shock, and the photosynthetic characteristics were investigated after heat stress treatment and recovery period. We believe that this study can reveal new insights in the understanding of mechanisms responsible for heat tolerance in tomato plants.

\section{Materials and methods}

Plant material and growth conditions: The experiments were performed from September to October 2018 in the
Venlo-type glasshouse of the Agricultural Meteorological Experiment Station located in Nanjing University of Information Science and Technology (NUIST), China $\left(32^{\circ} 14^{\prime} \mathrm{N}, 118^{\circ} 42^{\prime} \mathrm{E}\right)$. The Venlo-type glasshouse, with a north-south length of $30 \mathrm{~m}$, is composed of 12 spans, each 6- $\mathrm{m}$ wide in the east-west direction. The height of gutter and ridge was 4 and $4.73 \mathrm{~m}$, respectively. A popular tomato cultivar, 'JinGuan 5' (Lycopersicon esculentum Mill. cv. 'JinGuan 5'), was used as plant material. Tomato seedlings planted in plastic pots (pot depth was $18 \mathrm{~cm}$; pot diameter at the top and bottom was 24 and $16 \mathrm{~cm}$, respectively) were provided by Linyi Yuhong Seedling Planting Co., Ltd., China. The pots were filled with loam rich in organic matter with a $\mathrm{pH}$ of $6-7$, and the soil moisture was always maintained at $60-80 \%$, which were the most suitable conditions for tomato seedlings growth. When ten true leaves appeared on tomato seedlings, healthy and uniform seedlings were selected for the experimental treatment.

Experimental design and treatments: Healthy tomato seedlings with $15-\mathrm{cm}$ height and ten true leaves were transferred into artificial climate chambers (A1000, Conviron, Canada). One group exposed to $40^{\circ} \mathrm{C}$ for $4 \mathrm{~h}$ as the heat shock group, and another group with a temperature of $25^{\circ} \mathrm{C}$ for $4 \mathrm{~h}$ as the control group. The illumination and relative humidity of the artificial climate chamber were set to $1,000 \mu \mathrm{mol}$ (photon) $\mathrm{m}^{-2} \mathrm{~s}^{-1}$ and $65 \%$, respectively. The relative expression levels of heat shock proteins (HSP70, HSP90, and HSP110) in both groups were measured.

Both groups were then placed in a climate chamber with the temperature of $38 / 28^{\circ} \mathrm{C}$ (day/night, day from $6: 00$ to $18: 00 \mathrm{~h}$ ) for $48 \mathrm{~h}$ and then recovered at the temperature of $25 / 15^{\circ} \mathrm{C}$ for $48 \mathrm{~h}$. The photoperiod, illumination intensity, and relative humidity of the climate chamber were set to $12 / 12 \mathrm{~h}, 1,000 \mu \mathrm{mol}$ (photon) $\mathrm{m}^{-2} \mathrm{~s}^{-1}$, and $65 \%$, respectively. All indicators (photosynthetic parameters, $\mathrm{Chl}$ fluorescence parameters, electrolyte leakage, lipid peroxidation, ROS contents, and antioxidant enzymes activity) were measured $4 \mathrm{~h}$ after heat shock, $48 \mathrm{~h}$ after high temperature stress, and $48 \mathrm{~h}$ after recovery. All analyses were conducted in five replicates.

Relative expression levels of heat shock proteins: The HSP70, HSP90, and HSP110 gene sequences of tomato leaves were obtained from NCBI. PrimerQuest was used to design quantitative primers, and internal reference primers were designed based on tomato $\beta$-actin gene with determination of relative expression of three heat shock protein genes by qRT-PCR. Detailed determination of the relative expression level of three heat shock proteins were based on the method of $\mathrm{Hu}$ et al. (2010) and Piterková et al. (2013).

Gas-exchange parameters of tomato leaves were measured between 9:00-11:00 h by using the portable photosynthesis system LI-6400 (LI-COR Biosciences Inc., USA), and the $5^{\text {th }}$ to $8^{\text {th }}$ mature leaves from top to bottom were selected. The PAR was set to $1,000 \mu$ mol(photon) $\mathrm{m}^{-2} \mathrm{~s}^{-1}$, and the determination of each index was performed 
automatically by the $L I-6400$ built-in program. $P_{\mathrm{N}}$, transpiration rate $(E)$, stomatal conductance $\left(g_{\mathrm{s}}\right)$, and intercellular $\mathrm{CO}_{2}$ concentration $\left(C_{\mathrm{i}}\right)$ were measured. Stomatal limitation $\left(\mathrm{L}_{\mathrm{s}}\right)$ and water-use efficiency (WUE) were calculated as follows: $\mathrm{L}_{\mathrm{s}}=1-\mathrm{C}_{\mathrm{i}} / \mathrm{C}_{\mathrm{a}}$, where $\mathrm{C}_{\mathrm{a}}$ represents atmospheric $\mathrm{CO}_{2}$ concentration; WUE $=P_{\mathrm{N}} / E$.

Chl fluorescence parameters: The $5^{\text {th }}$ to $8^{\text {th }}$ fully expanded healthy leaves from the top were used to measure $\mathrm{Chl}$ fluorescence parameters by using a portable fluorometer (FMS 2, Hansatech, King's Lynn, UK). Minimal fluorescence $\left(\mathrm{F}_{0}\right)$, maximum fluorescence $\left(\mathrm{F}_{\mathrm{m}}\right)$, and variable fluorescence $\left(\mathrm{F}_{\mathrm{v}}\right)$ were automatically recorded by exposing the leaves to actinic light of 3,500 $\mu \mathrm{mol}$ (photon) $\mathrm{m}^{-2} \mathrm{~s}^{-1}$ after 20-min dark adaptation (leaves were shaded with clips). Then, the leaves were continuously illuminated with the actual growth light. Steady-state fluorescence in the light-adapted state $\left(\mathrm{F}_{\mathrm{s}}\right)$ and maximal fluorescence level in the light-adapted leaves $\left(\mathrm{F}_{\mathrm{m}}{ }^{\prime}\right)$ were collected. Based on the measurements described aboved, $\mathrm{F}_{\mathrm{v}} / \mathrm{F}_{\mathrm{m}}, \Phi_{\mathrm{PSII}}$, ETR, and NPQ were calculated by using following formulas: $\mathrm{F}_{\mathrm{v}} / \mathrm{F}_{\mathrm{m}}=\left(\mathrm{F}_{\mathrm{m}}-\mathrm{F}_{0}\right) / \mathrm{F}_{\mathrm{m}}, \Phi_{\text {PSII }}=\left(\mathrm{F}_{\mathrm{m}}{ }^{\prime}-\mathrm{F}_{\mathrm{s}}\right) / \mathrm{F}_{\mathrm{m}}{ }^{\prime}$, ETR $=0.84 \times$ $\Phi_{\text {PSII }} \times$ PAR $\times 0.5, \mathrm{NPQ}=\left(\mathrm{F}_{\mathrm{m}}-\mathrm{F}_{\mathrm{m}}{ }^{\prime}\right) / \mathrm{F}_{\mathrm{m}}{ }^{\prime}$, according to Zhang et al. (2018) and Maxwell and Johnson (2000).

Electrolyte leakage: Ten leaf samples with $10 \mathrm{~mm}$ in diameter were placed in 25-ml glass test tubes and rinsed three times with distilled water. We added $20 \mathrm{ml}$ of distilled water to test tubes and placed them in the dark for $18 \mathrm{~h}$ at room temperature. The electrical conductivity $\left(\mathrm{EC}_{1}\right)$ was measured by using an electrical conductivity meter (Jenway-4520, Bibby Scientific US, Burlington, USA). Then, test tubes were heated in the boiling water bath for $15 \mathrm{~min}$ and then cooled to room temperature, and the electrical conductivity $\left(\mathrm{EC}_{2}\right)$ was determined. Finally, electrolyte leakage was calculated according to the formula by Karlidag et al. $(2010)$ : $\left(\mathrm{EC}_{1} / \mathrm{EC}_{2}\right) \times 100 \%$.

Lipid peroxidation: Estimation of lipid peroxidation was based on MDA content. The MDA content was determined using the thiobarbituric acid (TBA) method (Camejo et al. 2006). The MDA content was calculated and expressed as nmol g-1(FM).

Active oxygen species analysis: Hydrogen peroxide $\left(\mathrm{H}_{2} \mathrm{O}_{2}\right)$ and superoxide anion $\left(\mathrm{O}_{2}{ }^{-}\right)$were extracted and determined based on the method of Chen et al. (2013) and Wang et al. (2018) with minor improvements. Here, samples of $0.5 \mathrm{~g}$ of fresh leaf tissue were ground to homogenate with $5 \mathrm{ml}$ of $5 \%(\mathrm{w} / \mathrm{v})$ trichloroacetic acid and then centrifuged at $3,000 \mathrm{rpm}$ at $4^{\circ} \mathrm{C}$ for $10 \mathrm{~min}$. The supernatant, with $17 \mathrm{M} \mathrm{NH}_{4} \mathrm{OH}$ added, was neutralized to $\mathrm{pH} 7.5$, and used for measurements.

For determination of $\mathrm{H}_{2} \mathrm{O}_{2}$ content, the extract was divided into two aliquots with $100 \mu \mathrm{l}$ each. One was added to 20 unit of CAT and the other was not added. Both two aliquots were added to $0.5 \mathrm{ml}$ with $100 \mathrm{mM}$ Tris- $\mathrm{HCl}$ $(\mathrm{pH} 8.0$ ) and kept at room temperature for $10 \mathrm{~min}$, and then $0.5 \mathrm{ml}$ of colorimetric reagent was added made by mixing an equal volume of $0.3 \mathrm{mM}$ 4-(2-pyridylazo) resorcinol monosodium salt and $0.3 \mathrm{mM}$ potassium titanium oxalate. The absorbance of the two reaction mixtures at a wavelength of $508 \mathrm{~nm}$ was determined using an ultraviolet spectrophotometer (UV-2450, Shimadzu, Japan) and then the difference of absorbance between the two aliquots was used to calculate the concentration of $\mathrm{H}_{2} \mathrm{O}_{2}$ using an extinction coefficient of $39.4 \mathrm{mM}^{-1} \mathrm{~cm}^{-1}$. The concentration of $\mathrm{H}_{2} \mathrm{O}_{2}$ was expressed as $\mu \mathrm{mol} \mathrm{g} \mathrm{g}^{-1}$ (FM).

For determination of $\mathrm{O}_{2}^{--}$production rate, the extract was divided into two aliquots with $100 \mu \mathrm{l}$ each. One of which was added to 50 unit of SOD and the other was not added. Both of the two aliquots were added to $0.9 \mathrm{ml}$ of $100 \mathrm{mM}$ Tris- $\mathrm{HCl}(\mathrm{pH} 7.5)$, and kept at room temperature for $10 \mathrm{~min}$, following the addition of $100 \mu \mathrm{l}$ of $5 \mathrm{mM}$ 2,3-bis(2-methoxy-4-nitro-5-sulfophenyl)-2Htetrazolium-5-carboxanilide inner salt. The absorbance of the two assay mixtures was analyzed at a wavelength of $470 \mathrm{~nm}$ using an ultraviolet spectrophotometer ( $U V-2450$, Shimadzu, Japan), and then the difference of absorbance between the two aliquots was used to calculate the concentration of $\mathrm{O}_{2}^{-}$using an extinction coefficient of $21.6 \mathrm{mM}^{-1} \mathrm{~cm}^{-1}$. The concentration of $\mathrm{O}_{2}{ }^{-}$was expressed as $\mathrm{mmol} \mathrm{min}^{-1} \mathrm{~g}^{-1}$.

Antioxidant enzyme assays: The $5^{\text {th }}$ to $8^{\text {th }}$ fully expanded leaves from the top were selected and placed in liquid nitrogen for freezing, and then stored at $-40^{\circ} \mathrm{C}$. Leaf samples $(0.5 \mathrm{~g})$ were ground in a mortar with $5 \mathrm{~mL}$ of phosphate buffer $\mathrm{pH} 7.8\left(0.2 \mathrm{~mol} \mathrm{~L} \mathrm{~L}^{-1} \mathrm{KH}_{2} \mathrm{PO}_{4}\right.$ and $0.2 \mathrm{~mol} \mathrm{~L}^{-1} \mathrm{~K}_{2} \mathrm{HPO}_{4}$ ) and a small amount of quartz sand placed in an ice bath. The homogenate was poured into a centrifuge tube and centrifuged at $4^{\circ} \mathrm{C} ; 4,000 \mathrm{rpm}$ for $20 \mathrm{~min}$. The supernatant was used for assay immediately.

Peroxidase (POD, EC 1.11.1.7) activity was determined by the increase in absorbance at $470 \mathrm{~nm}$ due to guaiacol oxidation (Meloni et al. 2003). One unit of POD activity was defined as the amount of the enzyme causing a change in absorbance at $470 \mathrm{~nm}$ of 0.01 per min. The specific POD activity was expressed as $\mathrm{U} \mathrm{g}^{-1}(\mathrm{FM}) \mathrm{min}^{-1}$.

Superoxide dismutase (SOD, EC 1.15.1.1) activity was measured by monitoring the inhibition of the photochemical reduction of nitroblue tetrazolium (NBT) (Zhu et al. 2004). One unit of SOD was defined as the amount of enzyme that produced $50 \%$ inhibition of NBT reduction under assay conditions. The specific SOD activity was expressed as $\mathrm{U} \mathrm{g}^{-1}(\mathrm{FM})$.

Catalase (CAT, EC 1.11.1.6) activity was assayed by monitoring the decline in absorbance at $240 \mathrm{~nm}$ due to decomposition of $\mathrm{H}_{2} \mathrm{O}_{2}$ (Luna et al. 2005). One CAT unit was defined as the amount of enzyme necessary to decompose $1 \mathrm{mM}\left(\mathrm{H}_{2} \mathrm{O}_{2}\right) \mathrm{min}^{-1}$ under the above-mentioned assay conditions. The specific CAT activity was expressed as $\mathrm{U} \mathrm{g}^{-1}(\mathrm{FM}) \mathrm{min}^{-1}$.

Statistical analysis: Data were analyzed with the SPSS version 17.0 for Windows (SPSS, Chicago, IL, USA). One-way analysis of variance (ANOVA) followed by Duncan's multiple range test between the treatments was used to detect the significance $(P<0.05)$. Figures were drawn with the GraphPad Prism version 7.05 for Windows 
(GraphPad Software, San Diego, CA, USA). The reported data were presented as the mean value \pm standard deviation (SD) of five replications.

\section{Results}

Relative expression levels of heat shock proteins: As it can be clearly seen from Fig. 1, the relative expression levels of HSP70, HSP90, and HSP110 in tomato leaves increased significantly after heat shock at $40^{\circ} \mathrm{C}$ for $4 \mathrm{~h}$. After $38 / 28^{\circ} \mathrm{C}$ regime for $4 \mathrm{~h}$, the contents of HSP70, HSP90, and HSP110 increased significantly in the control group. The content of HSP70 in heat shock group was significantly higher than that in the control group, but the contents of HSP90 and HSP110 were not significantly different from the control. After $25 / 15^{\circ} \mathrm{C}$ regime for 48 -h recovery, the contents of HSP70, HSP90, and HSP110 in the control group were not different from those before the high temperature treatment. The content of HSP70 in the heat shock group remained at a high level, and

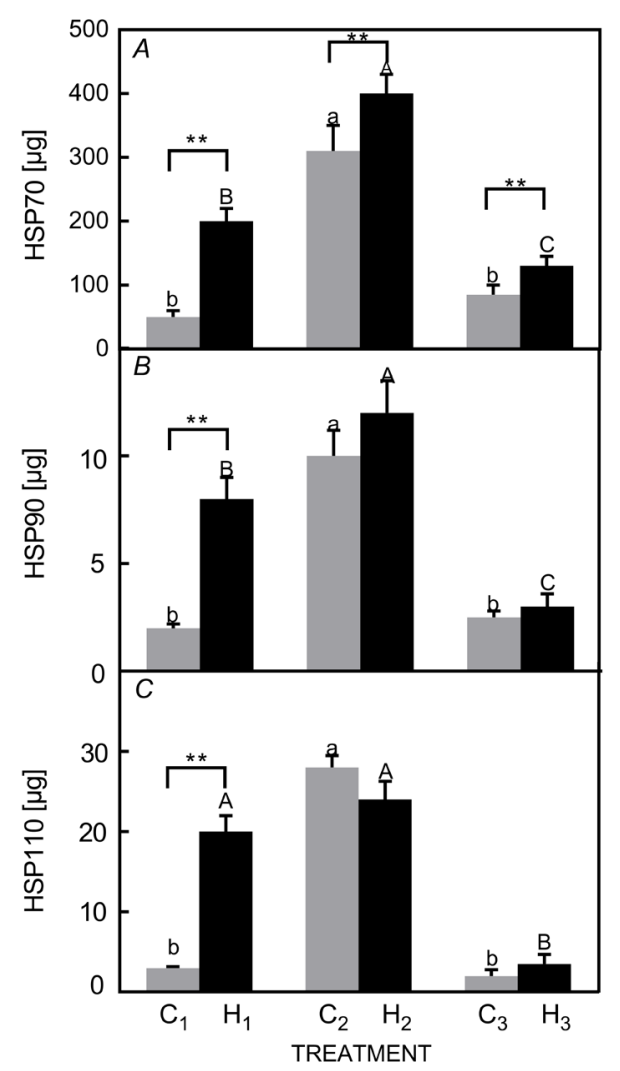

Fig. 1. Relative expression levels of heat shock protein (HSP) 70 (HSP70) $(A)$, HSP90 $(B)$, and HSP110 $(C)$ in tomato seedlings after heat shock, heat stress, and recovery. $\mathrm{C}_{1}$ - tomato seedlings being kept at $25^{\circ} \mathrm{C}$ for $4 \mathrm{~h}$ (control); $\mathrm{H}_{1}$ - tomato seedlings being kept at $40^{\circ} \mathrm{C}$ for $4 \mathrm{~h}$ (heat shock); $\mathrm{C}_{2}-\mathrm{C}_{1}$ followed by $38 / 28^{\circ} \mathrm{C}$ for $48 \mathrm{~h} ; \mathrm{H}_{2}-\mathrm{H}_{1}$ followed by $38 / 28^{\circ} \mathrm{C}$ for $48 \mathrm{~h} ; \mathrm{C}_{3}$ - recovery of tomato seedlings at $25 / 15^{\circ} \mathrm{C}$ for $48 \mathrm{~h}$ after $\mathrm{C}_{2} ; \mathrm{H}_{3}$ - recovery of tomato seedlings at $25 / 15^{\circ} \mathrm{C}$ for $48 \mathrm{~h}$ after $\mathrm{H}_{2}$. Different uppercase and lowercase letters represent significant differences at 0.01 and 0.05 level by Duncan's test, respectively. Values are means \pm SD, $n=15{ }^{* *}$ - significant difference at 0.01 level by Duncan's test. was significantly different from the control group, while the contents of HSP90 and HSP110 were lower and no significant difference was found from the control group.

Gas-exchange parameters: As it shown in Table 1, the heat shock at $40^{\circ} \mathrm{C}$ for $4 \mathrm{~h}$ significantly reduced $P_{\mathrm{N}}, g_{\mathrm{s}}$, $C_{\mathrm{i}}$, WUE, and $\mathrm{L}_{\mathrm{s}}$, but increased $E$ compared with control. Similarly, $P_{\mathrm{N}}, g_{\mathrm{s}}, C_{\mathrm{i}}$, WUE, and $\mathrm{L}_{\mathrm{s}}$ in the heat shock group were higher than those of the control group, but $E$ was lower than that in the control group after heat stress and recovery.

Chl fluorescence parameters: As shown in Fig. 2, compared with control, the heat shock at $40^{\circ} \mathrm{C}$ for $4 \mathrm{~h}$ slightly reduced the values of $\mathrm{F}_{\mathrm{v}} / \mathrm{F}_{\mathrm{m}}, \Phi_{\text {PSII }}$, and ETR, but significantly increased NPQ. The values of $F_{v} / F_{m}, \Phi_{\text {PSII, }}$ and ETR in the heat shock group were higher than those of the control group, but NPQ was significantly lower than that in the control group after heat stress and recovery.

Electrical conductivity and MDA content: Heat-shocked tomato seedlings reduced the electrical conductivity and MDA content in the leaves under high temperature stress and recovery (Fig. 3). Compared with the control, the heat shock at $40^{\circ} \mathrm{C}$ for $4 \mathrm{~h}$ slightly increased the electrical conductivity and MDA content. After $38 / 28^{\circ} \mathrm{C}$ for $48 \mathrm{~h}$, the electrical conductivity and MDA content in the control group were higher than those of the heat shock group, but the difference was not significant. However, after 48-h recovery at $25 / 15^{\circ} \mathrm{C}$, the electrical conductivity and MDA content of the control group were significantly higher than those of the heat shock group.

$\mathrm{H}_{2} \mathrm{O}_{2}$ content and $\mathrm{O}_{2}^{--}$production rate: Compared with the control, heat-shocked tomato seedlings decreased the $\mathrm{H}_{2} \mathrm{O}_{2}$ content and $\mathrm{O}_{2}{ }^{--}$production rate in tomato leaves under high temperature stress and recovery (Fig. 4). After $40^{\circ} \mathrm{C}$ for $4 \mathrm{~h}$ of heat shock, there was no difference in $\mathrm{H}_{2} \mathrm{O}_{2}$ content and $\mathrm{O}_{2}{ }^{-}$production rate between the heat-shock group and the control group. After high temperature stress, the content of $\mathrm{H}_{2} \mathrm{O}_{2}$ and $\mathrm{O}_{2}^{--}$production rate in the control group and the heat-shock group increased significantly, but the control group was slightly higher than the heatshock group. After $48 \mathrm{~h}$ recovery at $25 / 15^{\circ} \mathrm{C}$, both $\mathrm{H}_{2} \mathrm{O}_{2}$ content and $\mathrm{O}_{2}{ }^{-}$production rate in the control and heatshock groups were reduced, but the control group was significantly higher than the heat-shock group.

Antioxidant enzymes activities: As it can be seen from Fig. 5, tomato seedlings exposed to heat shock at $40^{\circ} \mathrm{C}$ for $4 \mathrm{~h}$ slightly increased the activities of CAT, SOD, and POD compared with the control. After $38 / 28^{\circ} \mathrm{C}$ for $48 \mathrm{~h}$, the activities of CAT, SOD, and POD in the heat-shock group were higher than those in the control group, but the difference was not significant. After $48 \mathrm{~h}$ recovery at $25 / 15^{\circ} \mathrm{C}$, the activities of CAT, SOD, and POD in the control and heat-shock groups increased, but the heatshock groups were higher than that of the control group.

Correlation analysis: Pearson's correlation analysis was 


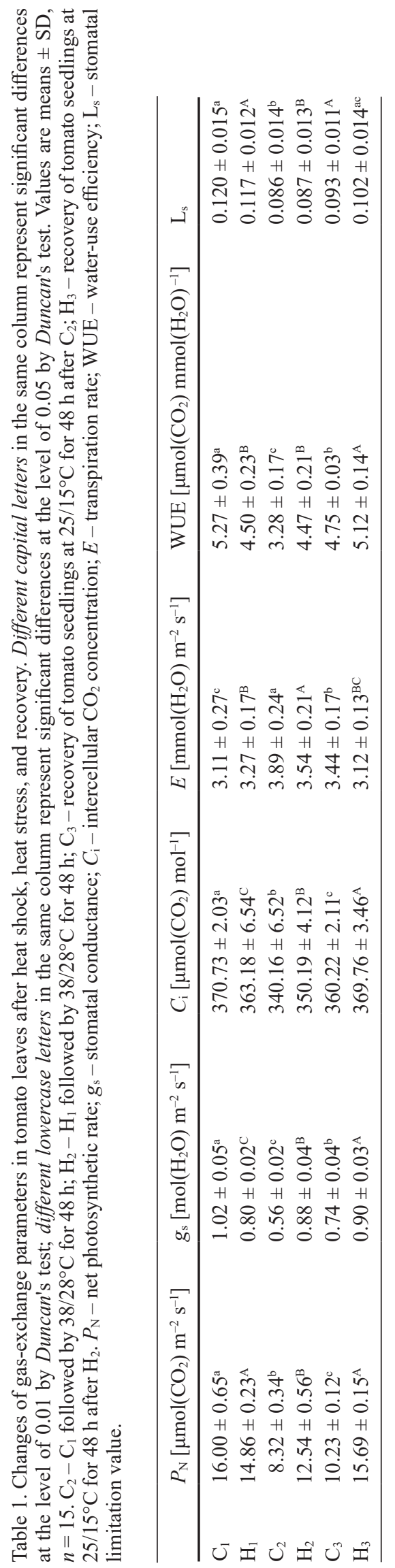

performed between photosynthetic parameters, MDA content, reactive oxygen species, antioxidant enzymes, and HSPs after high temperature stress. Table 2 shows that there was a significant negative correlation between HSP70 and $P_{\mathrm{N}}, \mathrm{F}_{\mathrm{v}} / \mathrm{F}_{\mathrm{m}}, \mathrm{SOD}, \mathrm{POD}$, and CAT, and a significant positive correlation with $\mathrm{MDA}, \mathrm{H}_{2} \mathrm{O}_{2}$, and $\mathrm{O}_{2}{ }^{\circ}$.

\section{Discussion}

Under high temperature stress, changes in the internal and external environment of plants inevitably affect the metabolism of proteins. High temperature-induced transcription and translation of HSPs has become a thermal protection mechanism for plants (Bita and Gerats 2013). In many plant species, heat tolerance of cells and tissues after high temperature stress depends almost on the induction of HSP70, though HSP100 has also been proven to be crucial (Gurley 2000). However, some studies showed that although some HSPs are essential for heat resistance, others play a less important role, for instance HSP101, HSA32, and HSFA3, because the knockout variants of these have a little effect on heat resistance (Sakata and Higashitani 2008, Yoshida et al. 2011). The results of this study indicated that HSPs are present in tomato seedlings under normal growth conditions, and heat shock can induce an increase in their synthesis. The HSPs content of heatinduced tomato seedlings after high temperature stress was significantly higher than that of the control group; also after $48 \mathrm{~h}$ of recovery, the HSPs content of the heatshock treatment group was still quite higher. Because the synthesis of HSPs and heat resistance are consistent, it is believed that heat-shock treatment increases the synthesis of HSPs and improves the heat tolerance of tomato seedlings. It is hypothesized that some of the HSPs play an important protective role in heat stress, protecting the structure of the cell membrane and the antioxidant system from damage, making tomato seedlings resistant to heat stress (Nover et al. 2001). Our experiments confirmed that heat shock-induced synthesis of HSP70 was closely related to the improvement of heat tolerance of tomato seedlings (Table 2), which is consistent with the study of Hahn et al. (2011).

$P_{\mathrm{N}}$ is an important indicator of photosynthesis and light-use efficiency, which directly reflects the state of photosynthetic apparatus (Lang et al. 2013). Transpiration is described as a method of cooling leaves subjected to thermal shock. In our study, the heat-treated tomato seedlings had higher $P_{\mathrm{N}}, C_{\mathrm{i}}$, WUE, $g_{\mathrm{s}}, \mathrm{L}_{\mathrm{s}}$, and had lower $E$ (Table 1), indicating that heat shock can improve the photosynthetic efficiency of tomato seedlings and resist the damage caused by high temperature stress. The $\Phi_{\text {PSII }}$ is an indicator of the photochemistry effective quantum yield of PSII reaction center. The decrease of $\Phi_{\text {PSII }}$ is considered to be the decrease of electron transfer rate and $\mathrm{CO}_{2}$ assimilation ability (Maxwell and Johnson 2000). The ETR reflects the electron transport rate in photochemical reactions. In this study, compared with the control, the heat-treated tomato seedlings had higher $\Phi_{\text {PSII }}$ and ETR after high temperature stress and recovery, indicating that the heat-shock treatment can improve the light energy 


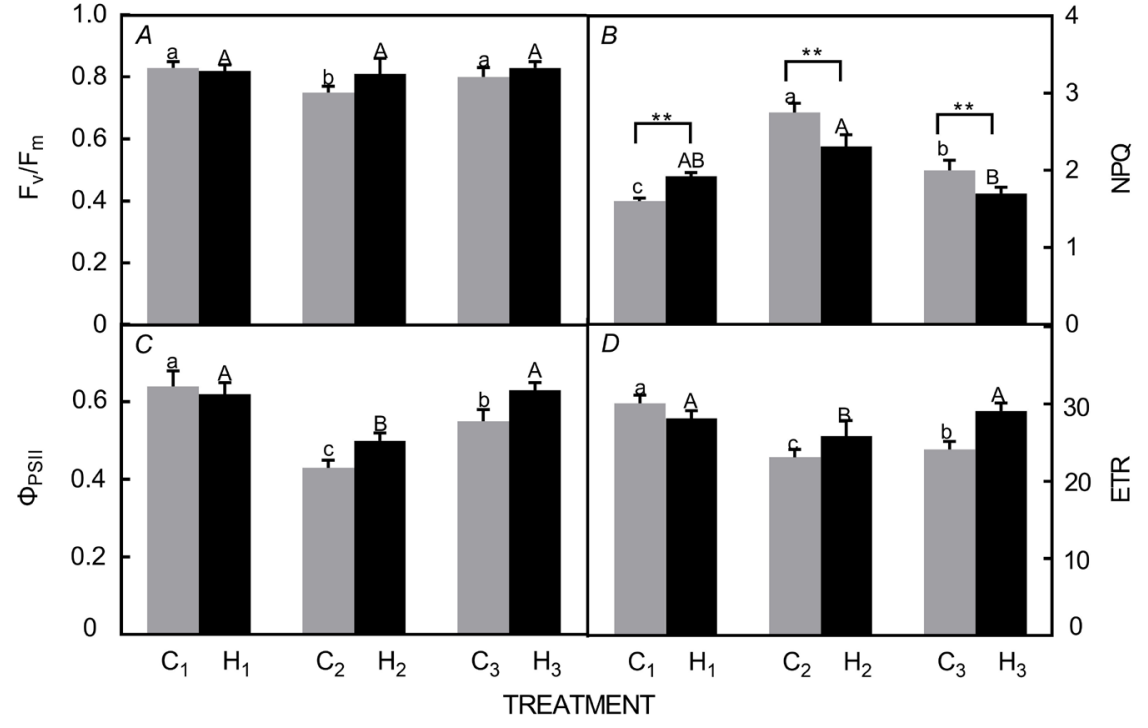

Fig. 2. Changes of maximal quantum yield of PSII photochemistry $\left(\mathrm{F}_{\mathrm{v}} / \mathrm{F}_{\mathrm{m}}\right)(A)$, nonphotochemical quenching (NPQ) $(B)$, actual photochemical efficiency of PSII $\left(\Phi_{\mathrm{PSII}}\right)(C)$, and electron transport rate (ETR) $(D)$ in tomato seedlings after heat shock, heat stress, and recovery. $\mathrm{C}_{2}-$ $\mathrm{C}_{1}$ followed by $38 / 28^{\circ} \mathrm{C}$ for $48 \mathrm{~h} ; \mathrm{H}_{2}-$ $\mathrm{H}_{1}$ followed by $38 / 28^{\circ} \mathrm{C}$ for $48 \mathrm{~h} ; \mathrm{C}_{3}-$ recovery of tomato seedlings at $25 / 15^{\circ} \mathrm{C}$ for $48 \mathrm{~h}$ after $\mathrm{C}_{2} ; \mathrm{H}_{3}$ - recovery of tomato seedlings at $25 / 15^{\circ} \mathrm{C}$ for $48 \mathrm{~h}$ after $\mathrm{H}_{2}$. Different uppercase and lowercase letters represent significant differences at 0.01 and 0.05 level by Duncan's test, respectively. Values are means $\pm \mathrm{SD}, n=15$. ** - significant difference at 0.01 level by Duncan's test.

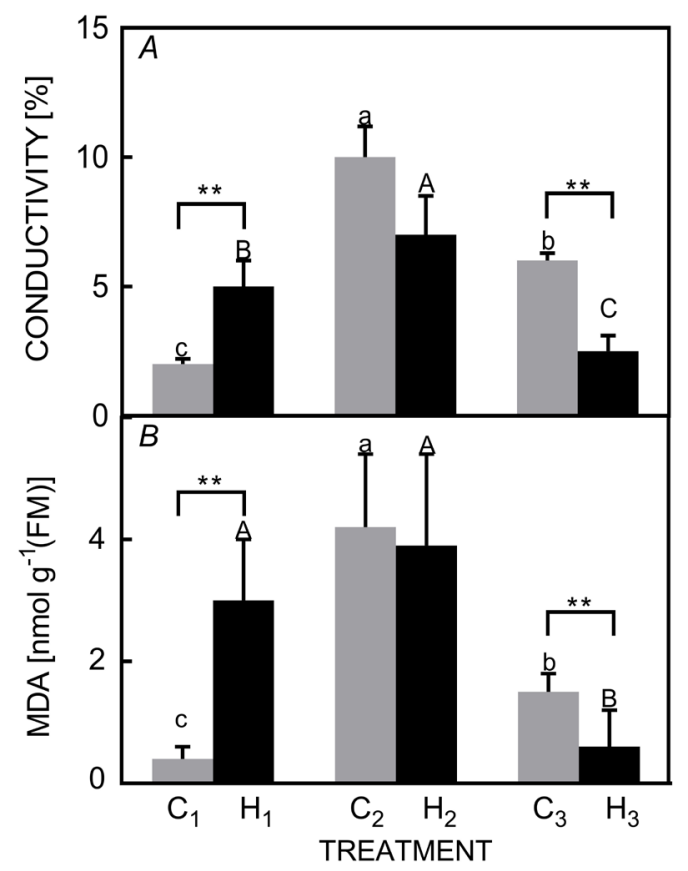

Fig. 3. Changes in relative conductivity $(A)$ and malondialdehyde (MDA) content $(B)$ of tomato seedlings after heat shock, heat stress, and recovery. $\mathrm{C}_{2}-\mathrm{C}_{1}$ followed by $38 / 28^{\circ} \mathrm{C}$ for $48 \mathrm{~h}$; $\mathrm{H}_{2}-\mathrm{H}_{1}$ followed by $38 / 28^{\circ} \mathrm{C}$ for $48 \mathrm{~h} ; \mathrm{C}_{3}$ - recovery of tomato seedlings at $25 / 15^{\circ} \mathrm{C}$ for $48 \mathrm{~h}$ after $\mathrm{C}_{2} ; \mathrm{H}_{3}$ - recovery of tomato seedlings at $25 / 15^{\circ} \mathrm{C}$ for $48 \mathrm{~h}$ after $\mathrm{H}_{2}$. Different uppercase and lowercase letters represent significant differences at 0.01 and 0.05 level by Duncan's test, respectively. Values are means \pm SD, $n=15$. ${ }^{* *}$ - significant difference at 0.01 level by Duncan's test.

conversion efficiency, electron transport rate, and $\mathrm{CO}_{2}$ assimilation ability of the PSII reaction centers. The NPQ reflects the ability of plants to dissipate excess light energy into heat, avoiding light damage, and also reflects the ability of plants to achieve photoprotection (Kanazawa and Kramer 2002). We found that compared with the

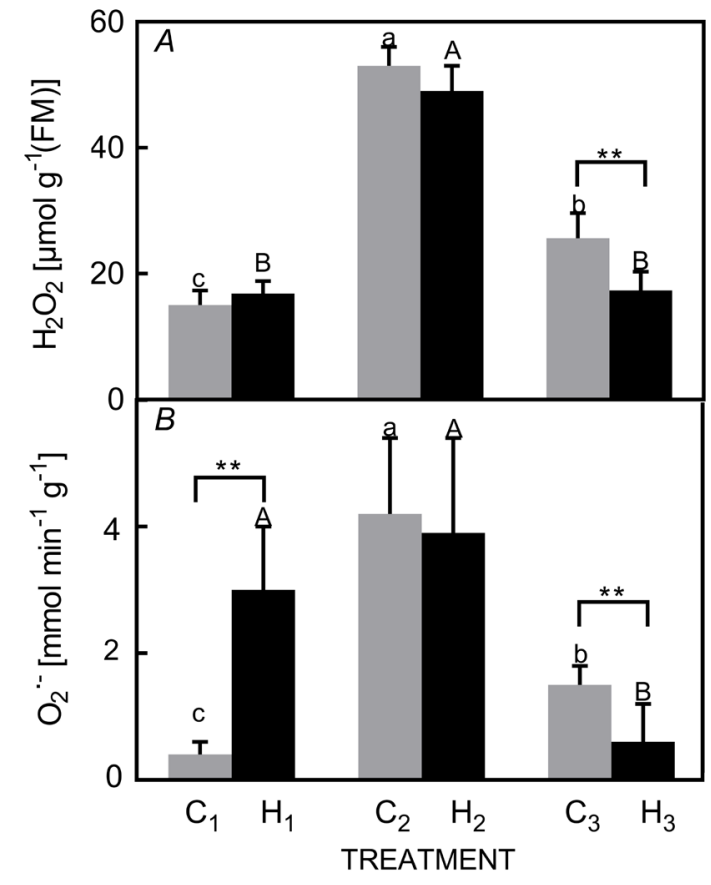

Fig. 4. Changes of $\mathrm{H}_{2} \mathrm{O}_{2}(A)$ and $\mathrm{O}_{2}^{-{ }^{-}}(B)$ in tomato leaves after heat shock, heat stress, and recovery. $\mathrm{C}_{2}-\mathrm{C}_{1}$ followed by $38 / 28^{\circ} \mathrm{C}$ for $48 \mathrm{~h} ; \mathrm{H}_{2}-\mathrm{H}_{1}$ followed by $38 / 28^{\circ} \mathrm{C}$ for $48 \mathrm{~h} ; \mathrm{C}_{3}-$ recovery of tomato seedlings at $25 / 15^{\circ} \mathrm{C}$ for $48 \mathrm{~h}$ after $\mathrm{C}_{2}$; $\mathrm{H}_{3}$ - recovery of tomato seedlings at $25 / 15^{\circ} \mathrm{C}$ for $48 \mathrm{~h}$ after $\mathrm{H}_{2}$. Different uppercase and lowercase letters represent significant differences at 0.01 and 0.05 level by Duncan's test, respectively. Values are means $\pm \mathrm{SD}, n=15{ }^{* *}$ - significant difference at 0.01 level by Duncan's test.

control, the NPQ of tomato seedlings treated by heat shock was smaller after high temperature stress and recovery, indicating that the heat-shock treatment increased the proportion of light energy absorbed by the antenna pigment used for the photochemical reaction, reducing the proportion for heat dissipation. $\mathrm{F}_{\mathrm{v}} / \mathrm{F}_{\mathrm{m}}$ reflects the quantum 


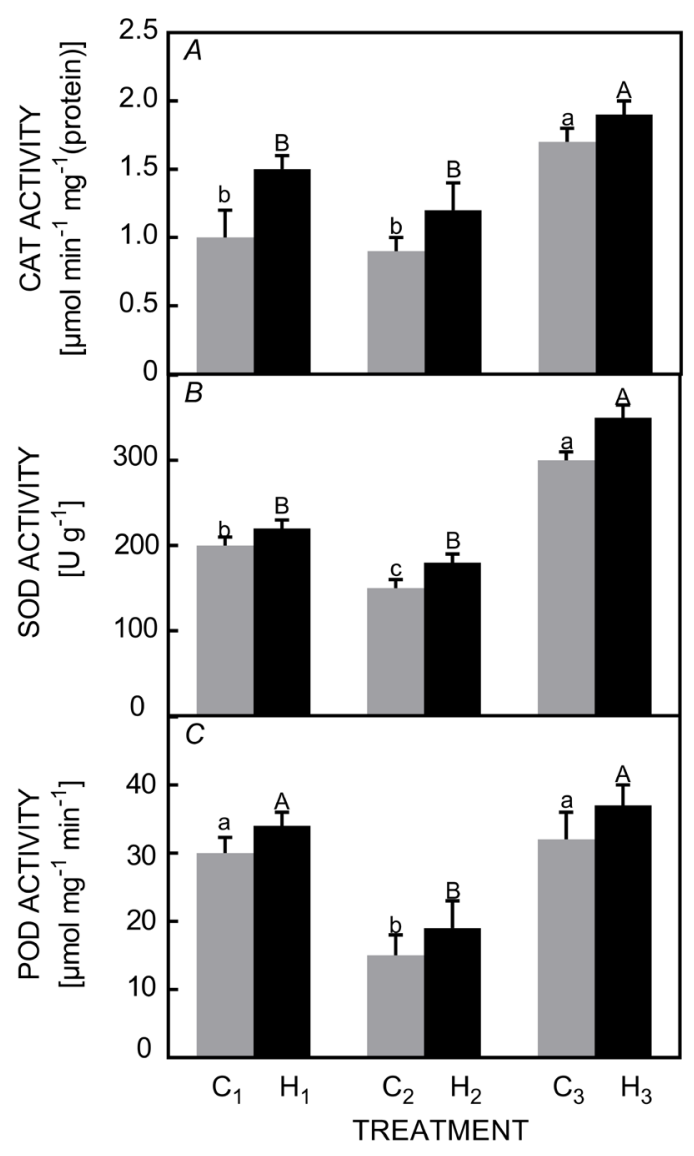

Fig. 5. Changes of catalase (CAT) $(A)$, superoxide dismutase (SOD) $(B)$, and peroxidase (POD) $(C)$ activity in tomato leaves after heat shock, heat stress, and recovery. $\mathrm{C}_{2}-\mathrm{C}_{1}$ followed by $38 / 28^{\circ} \mathrm{C}$ for $48 \mathrm{~h} ; \mathrm{H}_{2}-\mathrm{H}_{1}$ followed by $38 / 28^{\circ} \mathrm{C}$ for $48 \mathrm{~h}$; $\mathrm{C}_{3}$ - recovery of tomato seedlings at $25 / 15^{\circ} \mathrm{C}$ for $48 \mathrm{~h}$ after $\mathrm{C}_{2}$; $\mathrm{H}_{3}$ - recovery of tomato seedlings at $25 / 15^{\circ} \mathrm{C}$ for $48 \mathrm{~h}$ after $\mathrm{H}_{2}$. Different uppercase and lowercase letters represent significant differences at 0.01 and 0.05 level by Duncan's test, respectively. Values are means $\pm \mathrm{SD}, n=15$. yield when all PSII reaction centers are in an open state (Zhou et al. 2015). Under normal conditions, the value of $\mathrm{F}_{\mathrm{v}} / \mathrm{F}_{\mathrm{m}}$ is between 0.80 and 0.84 . When the plant is stressed, the $F_{v} / F_{m}$ is significantly lowered, which is considered to be a decrease in the efficiency of light energy conversion and a photoinhibition of the PSII reaction center (Maxwell and Johnson 2000, Prieto et al. 2009). In this paper, the heat-treated seedlings had higher $\mathrm{F}_{\mathrm{v}} / \mathrm{F}_{\mathrm{m}}$ compared with the control, indicating that the heat-treated seedlings had the higher heat tolerance.

Cell membrane is a sensitive site for high temperature damage in plants, and relative conductivity is an important indicator for describing the degree of injury to cell membranes (Zarrin et al. 2011). The MDA is one of the most important products of membrane lipid peroxidation with the production of free radicals that exceeds the removal ability of protective enzyme system (Tsikas 2017). Both leaf conductivity and MDA contents are important parameters reflecting stress tolerance of plants. In this paper, the results showed that tomato seedlings that had not been subjected to heat shock treatment had higher contents of active oxygen species, higher electrical conductivity, and MDA content after high temperature stress and recovery. We can conclude that high temperature seriously damaged the cells of tomato seedlings, and heat shock could alleviate heat stress. Antioxidant enzymes, such as POD, CAT, and SOD, are the most important enzymes for scavenging free radicals, maintaining the balance between free radical production and elimination in plant cells (Xie et al. 2018). There have been many reports on the comparative effects of SOD, CAT, and POD activities exposed to high temperature stress (Zhu et al. 2010, Yuan et al. 2011, Wang et al. 2014). For instance, high activities of SOD, CAT, and POD seem to be associated with the development of heat shock-induced heat tolerance in tomato seedlings (Camejo et al. 2006). Our results also found that the activities of antioxidant enzymes, such as CAT, SOD, and POD, of heat-shocked tomato seedlings were higher after heat-stress treatment

Table 2. Correlation analysis of various indicators after high temperature stress in tomato seedlings. ${ }^{*}$ and ${ }^{* *}$ indicate a significant correlation at the level of 0.05 and 0.01 by Duncan's test, respectively. $P_{\mathrm{N}}-$ net photosynthetic rate; $\mathrm{F}_{\mathrm{v}} / \mathrm{F}_{\mathrm{m}}-$ maximum photochemical efficiency of PSII; SOD - superoxide dismutase; POD - peroxidase; CAT - catalase; MDA - malondialdehyde content; HSP110 - heat shock protein 110; HSP 90 - heat shock protein 90; HSP70 - heat shock protein 70.

\begin{tabular}{|c|c|c|c|c|c|c|c|c|c|c|c|}
\hline & $P_{\mathrm{N}}$ & $\mathrm{F}_{\mathrm{v}} / \mathrm{F}_{\mathrm{m}}$ & SOD & POD & CAT & MDA & $\mathrm{H}_{2} \mathrm{O}_{2}$ & $\mathrm{O}_{2}^{\cdot-}$ & HSP110 & HSP90 & HSP70 \\
\hline$P_{\mathrm{N}}$ & 1 & 0.965 & 0.846 & $0.995^{*}$ & 0.945 & -0.866 & -0.964 & -0.866 & -0.822 & -0.946 & $-0.990^{* *}$ \\
\hline $\mathrm{F}_{\mathrm{v}} / \mathrm{F}_{\mathrm{m}}$ & & 1 & 0.956 & 0.933 & $0.997^{*}$ & -0.967 & -0.859 & -0.967 & -0.943 & $-0.998^{*}$ & $-0.963^{* *}$ \\
\hline SOD & & & 1 & 0.787 & 0.977 & $-0.999^{*}$ & -0.672 & $-0.999^{*}$ & $-0.999^{*}$ & -0.973 & $-0.843^{* *}$ \\
\hline POD & & & & 1 & 0.901 & -0.812 & -0.986 & -0.812 & -0.761 & -0.908 & $-0.995^{* *}$ \\
\hline CAT & & & & & 1 & -0.985 & -0.814 & -0.985 & -0.967 & $-0.905^{* *}$ & $-0.938^{* *}$ \\
\hline MDA & & & & & & 1 & 0.701 & $0.968^{* *}$ & $0.997^{*}$ & 0.982 & $0.864^{*}$ \\
\hline $\mathrm{H}_{2} \mathrm{O}_{2}$ & & & & & & & 1 & 0.701 & 0.641 & 0.825 & $0.965^{*}$ \\
\hline $\mathrm{O}_{2}^{\cdot-}$ & & & & & & & & 1 & $0.997^{*}$ & 0.982 & $0.864^{*}$ \\
\hline HSP110 & & & & & & & & & 1 & 0.963 & 0.825 \\
\hline HSP90 & & & & & & & & & & 1 & 0.944 \\
\hline HSP70 & & & & & & & & & & & 1 \\
\hline
\end{tabular}


and recovery, suggesting that heat shock-induced heat tolerance of tomato seedlings occurred.

Therefore, we concluded that short-term heat shock treatments induced the production of HSPs, which helped to improve the thermal tolerance of tomato seedlings.

\section{References}

Baker N.R.: Chlorophyll fluorescence: a probe of photosynthesis in vivo. - Annu. Rev. Plant Biol. 59: 89-113, 2008.

Begara-Morales J.C., Sánchez-Calvo B., Chaki M. et al.: Antioxidant systems are regulated by nitric oxide-mediated post-translational modifications (NO-PTMs). - Front. Plant Sci. 7: 152, 2016.

Bita C., Gerats T.: Plant tolerance to high temperature in a changing environment: Scientific fundamentals and production of heat stress-tolerant crops. - Front. Plant Sci. 4: 273, 2013.

Camejo D., Jiménez A., Alarcón J.J. et al.: Changes in photosynthetic parameters and antioxidant activities following heat-shock treatment in tomato plants. - Funct. Plant Biol. 33: 177-187, 2006.

Camejo D., Rodríguez P., Morales M.A. et al.: High temperature effects on photosynthetic activity of two tomato cultivars with different heat susceptibility. - J. Plant Physiol. 162: 281-289, 2005.

Chen C., Li H., Zhang D. et al.: The role of anthocyanin in photoprotection and its relationship with the xanthophyll cycle and the antioxidant system in apple peel depends on the light conditions. - Physiol. Plantarum 149: 354-366, 2013.

Gurley W.B.: HSP101: A key component for the acquisition of thermotolerance in plants. - Plant Cell 12: 457-460, 2000.

Hahn A., Bublak D., Schleiff E., Scharf K.D.: Crosstalk between Hsp90 and Hsp70 chaperones and heat stress transcription factors in tomato. - Plant Cell 23: 741-755, 2011.

Hatfield J.L., Prueger J.H.: Temperature extremes: Effect on plant growth and development. - Weather Clim. Extrem. 10: 4-10, 2015.

He X., Qiao Y., Liu Y. et al.: Environmental impact assessment of organic and conventional tomato production in urban greenhouses of Beijing city, China. - J. Clean. Prod. 134: 251-258, 2016.

$\mathrm{Hu}$ X., Liu R., Li Y. et al:: Heat shock protein 70 regulates the abscisic acid-induced antioxidant response of maize to combined drought and heat stress. - Plant Growth Regul. 60: 225-235, 2010.

Hütsch B.W., Jahn D., Schubert S.: Grain yield of wheat (Triticum aestivum L.) under long-term heat stress is sinklimited with stronger inhibition of kernel setting than grain filling. - J. Agron. Crop Sci. 205: 22-32, 2019.

Kanazawa A., Kramer D.M.: In vivo modulation of nonphotochemical exciton quenching (NPQ) by regulation of the chloroplast ATP synthase. - P. Natl. Acad. Sci. USA 99: 12789-12794, 2002.

Karlidag H., Esitken A., Yildirim E. et al.: Effects of plant growth promoting bacteria on yield, growth, leaf water content, membrane permeability, and ionic composition of strawberry under saline conditions. - J. Plant Nutr. 34: 34-45, 2010.

Keeler S.J., Boettger C.M., Haynes J.G. et al.: Acquired thermotolerance and expression of the HSP $100 / \mathrm{ClpB}$ genes of lima bean. - Plant Physiol. 123: 1121-1132, 2000.

Kissoudis C., Chowdhury R., van Heusden S. et al:: Combined biotic and abiotic stress resistance in tomato. - Euphytica 202: 317-332, 2015.

Lang Y., Wang M., Zhang G. et al.: Experimental and simulated light responses of photosynthesis in leaves of three tree species under different soil water conditions. - Photosynthetica 51: 370-378, 2013.

Li S., Li F., Wang J. et al.: Glycinebetaine enhances the tolerance of tomato plants to high temperature during germination of seeds and growth of seedlings. - Plant Cell Environ. 34: 19311943, 2011.

Liang G.T., Zhang S.Y., Guo J. et al.: The effects of parahydroxybenzoic acid treatment on photosynthetic parameters of Populus $\times$ euramericana "Neva". - Photosynthetica 56: 505-511, 2018.

Lindquist S., Craig E.A.: The heat-shock proteins. - Annu. Rev. Genet. 22: 631-677, 1988.

Lu T., Meng Z., Zhang G. et al:: Sub-high temperature and high light intensity induced irreversible inhibition on photosynthesis system of tomato plant (Solanum lycopersicum L.). - Front. Plant Sci. 8: 365, 2017.

Luna C.M., Pastori G.M., Driscoll S. et al.: Drought controls on $\mathrm{H}_{2} \mathrm{O}_{2}$ accumulation, catalase (CAT) activity and CAT gene expression in wheat. - J. Exp. Bot. 56: 417-423, 2005.

Lurie S., Klein J.D.: Acquisition of low-temperature tolerance in tomatoes by exposure to high-temperature stress. - J. Am. Soc. Hortic. Sci. 116: 1007-1012, 1991.

Mahat D.B., Salamanca H.H., Duarte F.M. et al.: Mammalian heat shock response and mechanisms underlying its genomewide transcriptional regulation. - Mol. Cell 62: 63-78, 2016.

Maxwell K., Johnson G.N.: Chlorophyll fluorescence a practical guide. - J. Exp. Bot. 51: 659-668, 2000.

Meloni D.A., Oliva M.A., Martinez C.A., Cambraia J.: Photosynthesis and activity of superoxide dismutase, peroxidase and glutathione reductase in cotton under salt stress. Environ. Exp. Bot. 49: 69-76, 2003.

Nover L., Bharti K., Döring P. et al.: Arabidopsis and the heat stress transcription factor world: How many heat stress transcription factors do we need? - Cell Stress Chaperon. 6: 177-189, 2001.

Piterková J., Luhová L., Mieslerová B. et al.: Nitric oxide and reactive oxygen species regulate the accumulation of heat shock proteins in tomato leaves in response to heat shock and pathogen infection. - Plant Sci. 207: 57-65, 2013.

Prieto P., Peñuelas J., Llusià J. et al:: Effects of longterm experimental night-time warming and drought on photosynthesis, $F_{v} / F_{m}$ and stomatal conductance in the dominant species of a Mediterranean shrubland. - Acta Physiol. Plant. 31: 729-739, 2009.

Sakata T., Higashitani A.: Male sterility accompanied with abnormal anther development in plants: Genes and environmental stresses with special reference to high temperature injury. - Int. J. Plant Dev. Biol. 2: 42-51, 2008.

Takahashi S., Murata N.: How do environmental stresses accelerate photoinhibition? - Trends Plant Sci. 13: 178-182, 2008.

Tedeschi J.N., Kennington W.J., Tomkins J.L. et al.: Heritable variation in heat shock gene expression: A potential mechanism for adaptation to thermal stress in embryos of sea turtles. - P. R. Soc. B 283: 671-682, 2016.

Tsikas D.: Assessment of lipid peroxidation by measuring malondialdehyde (MDA) and relatives in biological samples: Analytical and biological challenges. - Anal. Biochem. 524: 13-30, 2017.

Usman M.G., Rafii M.Y., Ismail M.R. et al.: Heat shock proteins: Functions and response against heat stress in plants. - Int. J. Sci. Technol. Res. 3: 204-218, 2014.

Wang C., Wen D., Sun A. et al.: Differential activity and expression of antioxidant enzymes and alteration in osmolyte accumulation under high temperature stress in wheat 
seedlings. - J. Cereal Sci. 60: 653-659, 2014.

Wang Z., Wang Y., Zhao J. et al.: Effects of $\mathrm{GeO}_{2}$ on chlorophyll fluorescence and antioxidant enzymes in apple leaves under strong light. - Photosynthetica 56: 1081-1092, 2018.

Xie D., Zhang G., Xia X. et al.: The effects of phenolic acids on the photosynthetic characteristics and growth of Populus $\times$ euramericana cv. 'Neva'seedlings. - Photosynthetica 56: 981988, 2018.

Xu W., Cai S.Y., Zhang Y. et al.: Melatonin enhances thermotolerance by promoting cellular protein protection in tomato plants. - J. Pineal. Res. 61: 457-469, 2016.

Yoshida T., Ohama N., Nakajima J. et al:: Arabidopsis HsfA1 transcription factors function as the main positive regulators in heat shock-responsive gene expression. - Mol. Genet. Genomics 286: 321-332, 2011.

Yuan Y., Liu Y., Luo Y. et al.: High temperature effects on flavones accumulation and antioxidant system in Scutellaria baicalensis Georgi cells. - Afr. J. Biotechnol. 10: 5182-5192, 2011.

Zarrin H., Higgins D., Jun Y. et al.: Functionalized graphene oxide nanocomposite membrane for low humidity and high temperature proton exchange membrane fuel cells. - J. Phys. Chem. C 115: 20774-20781, 2011.

Zhang B.B., Xu J.L., Zhou M. et al.: Effect of light quality on leaf photosynthetic characteristics and fruit quality of peach (Prunus persica L. Batch). - Photosynthetica 56: 1113-1122, 2018.

Zhou R., Yu X., Kjær K.H. et al.: Screening and validation of tomato genotypes under heat stress using $\mathrm{F}_{\mathrm{v}} / \mathrm{F}_{\mathrm{m}}$ to reveal the physiological mechanism of heat tolerance. - Environ. Exp. Bot. 118: 1-11, 2015.

Zhu X., Song F., Xu H.: Influence of arbuscular mycorrhiza on lipid peroxidation and antioxidant enzyme activity of maize plants under temperature stress. - Mycorrhiza 20: 325-332, 2010.

Zhu Z., Wei G., Li J. et al.: Silicon alleviates salt stress and increases antioxidant enzymes activity in leaves of saltstressed cucumber (Cucumis sativus L.). - Plant Sci. 167: 527-533, 2004.

(C) The authors. This is an open access article distributed under the terms of the Creative Commons BY-NC-ND Licence. 